Apidologie, 1985, 16 (4), 385-394

\title{
EFFECT OF DIETARY VITAMIN C LEVELS ON THE RATE OF BROOD PRODUCTION OF FREE-FLYING AND CONFINED COLONIES OF HONEY BEES
}

\author{
E.W. HERBERT Jr. *, J.T. VANDERSLICE ** and D.J. HIGGS ** \\ *U.S. Department of Agriculture, Agricultural Research Service, PPI, \\ Bioenvironmental Bee Laboratory, Beltsville, MD 20705 \\ $\because:$ U.S. Department of Agriculture, Agricultural Research Service, PPI, \\ HNRC, Nutrient Composition Laboratory, Beltsville, MD 20705
}

\begin{abstract}
SUMMARY
The effect of dietary vitamin $\mathrm{C}$ on brood rearing of honey bees was studied using both free-flying and confined colonies. Pollen traps were placed on free-flying colonies for a $3 \mathrm{hr}$ period and the weight of pollen and levels of vitamin $\mathbf{C}$ (L-ascorbic acid and dehydroascorbic acid) were determined. The amount of sealed brood in each of these colonies was also measured. Additionally the consumption and brood rearing by caged bees fed a pollen substitute fortified with $0,500,1000$, or $2000 \mu \mathrm{g} \mathrm{L-ascorbic} \mathrm{acid/g} \mathrm{diet} \mathrm{were} \mathrm{measured.} \mathrm{Pollen} \mathrm{proved} \mathrm{to} \mathrm{be} \mathrm{a} \mathrm{rich}$ but variable source of Vitamin $C$ depending on the date of collection and floral source. There was, however, no relationship between the vitamin $C$ level in the pollen collected and the rate of brood rearing. There were highly significant differences in the vitamin $\mathrm{C}$ levels in pollen depending on the date of collection. In the study using caged bees, significantly more brood was reared by bees fed either the diet supplemented with $500 \mu \mathrm{g} / \mathrm{g}$ or the control than by bees offered diets containing either 1000 or $2000 \mu \mathrm{g} / \mathrm{g} \mathrm{L}$-ascorbic acid. This study also demonstrated for the first time that bees are able to produce this vitamin since prepupae from colonies fed the diets without vitamin $\mathrm{C}$ had equivalent levels of ascorbic acid to those fed the enriched diets.
\end{abstract}

\section{INTRODUCTION}

Honey bee nutritional studies utilizing synthetic or semi-synthetic diets have often included the B-vitamin complex since these vitamins are necessary for normal brood rearing (Back, 1956 ; Serian-Back, 1961 ; Haydak and Dietz, 1965, 1972 and ANDERSON and DiETZ, 1976). Most often vitamin C has not been incorporated into these diets, and to date the precise functions and requirements of vitamin $\mathrm{C}$ for honey bees have not been demonstrated. 
Pollen, the high protein and vitamin diet of honey bees, is a rich source of vitamin $\mathrm{C}$. The levels of vitamin $\mathrm{C}$ in bee-collected pollen have been reported by several investigators (VIvino and PALMER, 1944 ; HAgedorn and Burger, 1968 ; Herbert et al., 1985). Herbert et al. showed that the level varies considerably depending on floral source of the pollen and time of year. The levels of vitamin $\mathrm{C}$ ranged from $136 \mathrm{ug} / \mathrm{g}$ pollen (collected in Aug) to $1943 \mathrm{ug} / \mathrm{g}$ pollen (collected in May).

Ascorbic acid undergoes rapid oxidation upon storage and changes from the active forms of the vitamin (ascorbic acid and dehydroascorbic acid) to nonactive products. HAGEDORN and BURGER (1968) found that the ascorbic acid content of pollen decreased with the age of pollen, as did the effectiveness of pollen for brood rearing, hypopharyngeal gland development, and rate of growth of honey bees. Previous studies on the levels of vitamin $\mathrm{C}$ in pollen may be underestimated since the pollen samples were often not «fresh» and only ascorbic acid was determined not both ascorbic acid and dehydroascorbic acid.

Caged honey bees fed a synthetic diet reared the most bees to the sealed stage when the diet was supplemented with the highest levels of ascorbic acid (HERBERT et al., 1985). This study suggested a possible relationship between vitamin C levels in diet and the amount of brood rearing. The present study as conducted to further elucidate this possible relationship by : 1) determining the amount of pollen collected and levels of vitamin $\mathrm{C}$ in samples collected from free-flying colonies of honey bees ; 2) to measure the amount of sealed brood in each of these colonies and 3 ) to measure the brood rearing and diet consumption of caged bees fed a pollen substitute fortified with various levels of L-ascorbic acid.

\section{MATERIALS AND METHODS}

\section{Free-flying honey bees}

Eight colonies established from 3-1b packages on 15 April 1984 were located at four sites in Beltsville, MD, hereafter referred to as Apiary site (APRY), Pesticide Road site (PEST), Poultry Road site (POUL), and power line site (POWR). Two colonies were established at each location. A simple entrance trap (STEWart and SHImanuKI, 1970) was placed in the entrance of each colony biweekly (between 1000 and $1300 \mathrm{hr}$ ) from May to September 1984.

Colonies were inspected biweekly (the day after the pollen collection) and the amount of sealed brood measured in each colony using a wire grid divided into $6.45 \mathrm{~cm}^{2}$ units. The colonies remained free of disease during the test period.

The pollen samples were weighed and analyzed for L-ascorbic acid and dehydroascorbic acid immediately after collection. A high performance liquid chromatographic (HPLC) procedure based on the method of VANDERSLICE and Higgs (1984) was used for the analysis. Total analysis time including extraction was approximately $40 \mathrm{~min}$. 
The pollen sample $(1 \mathrm{~g})$, to which $5 \mathrm{mg}$ of pyrogallol was added as an anti-oxidant, was vortexed in a $10-\mathrm{ml}$ degassed solution of $0.1 \mathrm{M}$ citric acid for 1 min under $\mathrm{N}_{2}$ gas. Subsequently, the denatured solution was vortexed with $10 \mathrm{ml}$ of $\mathrm{CH}_{2} \mathrm{Cl}_{2}$ for $1 \mathrm{~min}$ to remove lipid material, and then centrifuged for $10 \mathrm{~min}$ at $2400 \mathrm{~g}$. The water layer was then removed, filtered through a $0.45-\mu \mathrm{m}$ filter (Millipore Corporation, Bedford, MA), and $500 \mu \mathrm{l}$ was injected into an anion exchange column. The ascorbic acid was oxidized postcolumn to dehydroascorbic acid and both eluting species were reacted with orthophenylene diamine (OPD) to form a fluorescent compound for detection purposes. The HPLC column $(6 \times 300 \mathrm{~mm})$ was packed with $6 \times 230 \mathrm{~mm}$ of Aminex A-25 resin (Bio-Rad Corporation, Richmond, CA). The eluting buffer was $0.1 \mathrm{M}$ citric acid, $0.7 \mathrm{M} \mathrm{NaCl}$, and $0.005 \mathrm{M}$ EDTA at $\mathrm{pH} 3.8$. The oxidizing agent was $2.5 \mathrm{mM} \mathrm{HgCl}_{2}$ dissolved in the same buffered solution and the concentration of OPD was $3.2 \mathrm{mM}$, again dissolved in the same buffer solution. The oxidation step occurred in only $11 \mathrm{~cm}$ of tubing whereas the subsequent $O P D$ reaction required $4.5 \mathrm{~m}$ of tubing immersed in a water bath at $70^{\circ} \mathrm{C}$. All tubing was Teflon with an ID of $0.40 \mathrm{~mm}$. Detection was by fluorescence (Fluoromonitor, Aminco, Silver Spring, MD). The primary filter was a Corning 7-60 (Corning Glass, Corning, NY), and the secondary filter was a Wratten 2E (Eastman Kodak Company, Rochester, NY).

\section{Caged honey bees}

A pollen substitute (Herbert and Shimanuki, 1981) containing 0, 500, 1000 , or $2000 \mu \mathrm{g}$ ascorbic acid $/ \mathrm{g}$ diet was made available to colonies of bees (four colonies for each diet regime) by placing $50 \mathrm{~g}$ of diet in a plastic Petri dish lid $(15 \times 100 \mathrm{~mm})$ that was inverted over the top bars of a miniature hive $(23 \times 19 \times 25 \mathrm{~cm})$. The test colonies were each established with $400 \mathrm{~g}$ of newly emerged Italian bees (ca. 4000 bees) and a mated laying queen. Each hive contained five drawn shallows combs $(3 \times 16 \times 24 \mathrm{~cm})$ free of any pollen or honey. The colonies were confined in screen flight $(2 \times 2 \times 2 \mathrm{~m})$ to prevent the collection of pollen. Two colonies offered the same diet were placed in each cage. As soon as the first sealed brood appeared, the number of sealed cells was counted and then biweekly thereafter. Periodically during the study, samples of prepupae were removed from colonies offered each diet and total vitamin $C$ (L-ascorbic acid and dehydroascorbic acid) determinations were made. Approximately $1 \mathrm{~g}$ samples of prepupae were extracted and analyzed for the vitamin by the same methods for pollen except that the samples were homogenized rather than vortexed.

The design of the experiment using free-flying honey bees was a completely random design with 11 repeated measures from May to September 1984. The data were analyzed by analysis of variance including the site, date and the site by date interaction. Site means were compared by Duncan's multiple range test. An analysis of covariance was run to examine the effects of vitamin $\mathrm{C}$ on $\log _{10}$ brood. The data using caged honey bees were analyzed by analysis of variance and differences were grouped by week according to Duncan's multiple range test.

\section{Free Flying Bees}

\section{RESULTS}

The weight of pollen collected and the total vitamin C levels (L-ascorbic acid and dehydroascorbic acid) in fresh bee collected pollen are presented in table 1. The pollen samples were collected biweekly from 4 May until 18 Sept. The data were analyzed by removing observations (dates) where either pollen collections, vitamin $\mathrm{C}$ levels or brood measurements were missing. On 20 Aug the two colonies at each location at PEST and POWR sites failed to collect pollen during our 3-hr sampling period. Also one colony at the POWR 
TABL. 1. - Weight of pollen (1) collected $(g)$

and the least squares means for vitamin $C(\mu g /$ pollen $)$ by date and site

\begin{tabular}{|c|c|c|c|c|c|c|c|c|}
\hline \multirow{3}{*}{ Date } & \multicolumn{8}{|c|}{ Sites } \\
\hline & \multicolumn{2}{|c|}{ APRY } & \multicolumn{2}{|c|}{ PEST } & \multicolumn{2}{|c|}{ POUL } & \multicolumn{2}{|c|}{ POWR } \\
\hline & Pollen & Vitamin C & Pollen & Vitamin $C$ & Pollen & Vitamin C & Pollen & Vitamin $\mathrm{C}$ \\
\hline 4 May & 13.1 & 1906.50 & 4.8 & 1258.50 & 8.3 & 1370.50 & 8.9 & 1341.70 \\
\hline 18 May & 1.0 & 1431.50 & 16.8 & 1460.50 & 12.3 & 1250.83 & 22.7 & 1443.00 \\
\hline 31 May & 28.2 & 1102.50 & 40.4 & 723.92 & 40.5 & 1013.83 & 37.4 & 907.30 \\
\hline 13 June & 2.7 & 540.00 & 5.0 & 516.50 & 1.6 & 540.00 & 1.2 & 540.00 \\
\hline 25 June & 2.0 & 776.50 & 0.6 & 362.92 & 3.1 & 669.83 & 2.0 & 557.30 \\
\hline 9 July & 13.1 & 694.00 & 7.8 & 524.50 & 21.3 & 645.00 & 25.0 & 876.00 \\
\hline 23 July & 39.4 & 296.50 & 3.0 & 233.92 & 8.6 & 272.50 & 1.9 & 549.00 \\
\hline 6 August & 57.0 & 241.50 & 2.6 & 258.50 & 22.6 & 334.00 & 27.3 & 273.00 \\
\hline 4 September & 1.1 & 387.50 & 0.7 & 320.08 & 1.8 & 435.83 & 1.1 & 444.30 \\
\hline 18 September & 22.4 & 544.50 & 27.9 & 450.00 & 53.8 & 530.00 & 20.6 & 378.50 \\
\hline
\end{tabular}

(1) Total collected by two colonies of bees at each site.

site was queenless on 31 May and was immediately requeened. In general, the vitamin $\mathrm{C}$ exists in its ascorbic acid from with little dehydroascorbic present. There were highly significant differences in the vitamin $\mathrm{C}$ levels in pollen depending on the date of collection. The vitamin $\mathrm{C}$ values, by date over all sites, show the greatest levels were in pollen collected on 4 May and the smallest levels on 6 Aug. There were significant differences in the amount of Vitamin $\mathrm{C}$ in pollen depending on the date and site and the site $X$ date interaction was significant. The mean vitamin $\mathrm{C}$ levels by site (over all dates) showed the highest levels of vitamin $\mathrm{C}$ in pollen collected by bees at the APRY site and the least at the PEST site.

An analysis of variance of the weight of pollen collected showed that the only significant difference was dates of collection with the most pollen collected on 31 May and the smallest amount on 4 Sept. There were, however, no site differences in the amount of pollen collected by bees for all dates.

The interaction of brood rearing, vitamin $\mathrm{C}$ levels, and weight of pollen collected are shown in tables 2 and 3 . No differences in brood rearing were found. There were also no significant differences between site and site $\times$ date. Though not significantly different, most brood rearing occurred at the POUL site and the least at the POWR site. Brood rearing by date (over all sites) showed that most brood was present on 31 May and the smallest amount on 18 Sept. 
TABL. 2. - The least squares means by sites of brood $\left(\mathrm{cm}^{2}\right)$, vitamin $C(\mu \mathrm{g} / \mathrm{g}$ pollen) and pollen weights $(\mathrm{g})$ of free flying colonies of honey bees

\begin{tabular}{r|c|c|c}
\hline \multicolumn{1}{c|}{ Date (1) } & Brood (2) & Vitamin C & Weight of Pollen \\
\hline 4 May & 1,437 & 1,469 & 8.4 \\
18 May & 1,404 & 1,396 & 5.7 \\
31 May & 2,959 & 936 & 27.9 \\
13 June & 1,983 & 534 & 0.9 \\
25 June & 1,099 & 591 & 1.9 \\
9 July & 2,067 & 684 & 8.0 \\
23 July & 2,093 & 338 & 7.0 \\
6 August & 2,528 & 276 & 13.0 \\
4 September & 908 & 396 & 0.0 \\
18 September & 936 & 475 & 15.3 \\
\hline
\end{tabular}

(1) Dates are averaged across all sites.

(2) Brood is the geometric means of four replications.

TABL. 3. - The least square means by dates of brood $\left(\mathrm{cm}^{2}\right)$, vitamin $C(\mu \mathrm{g} / \mathrm{g}$ pollen) and pollen weight $(\mathrm{g})$ of free-flying colonies of honey bees

\begin{tabular}{l|c|c|c}
\hline \multicolumn{1}{c|}{ Site (1) } & Brood (2) & Vitamin C & Weight of Pollen \\
\hline APRY & 1,561 & 792 & 10.9 \\
PEST & 1,854 & 610 & 6.1 \\
POUL & 2,099 & 706 & 9.3 \\
POWR & 1,120 & 731 & 7.8 \\
\hline
\end{tabular}

(1) Sites are averaged across all dates.

(2) Brood is the geometric means of four replications.

An analysis of covariance was run to examine the effects of vitamin $\mathrm{C}$ on $\log _{10}$ brood. This analysis tests the association of vitamin $C$ with $\log$ brood and the site and date effects adjusted to a constant vitamin C level (680 19). This test also removed observations where either vitamin $C$ levels or brood measurements were missing. This analysis decreased the degrees of freedom from 87 to 61 . The test further demonstrated the lack of relationship between the vitamin $C$ levels in pollen and the rate of brood rearing over all dates and sites since a small percentage of the variation in brood was associated with change in vitamin $\mathrm{C}$. 


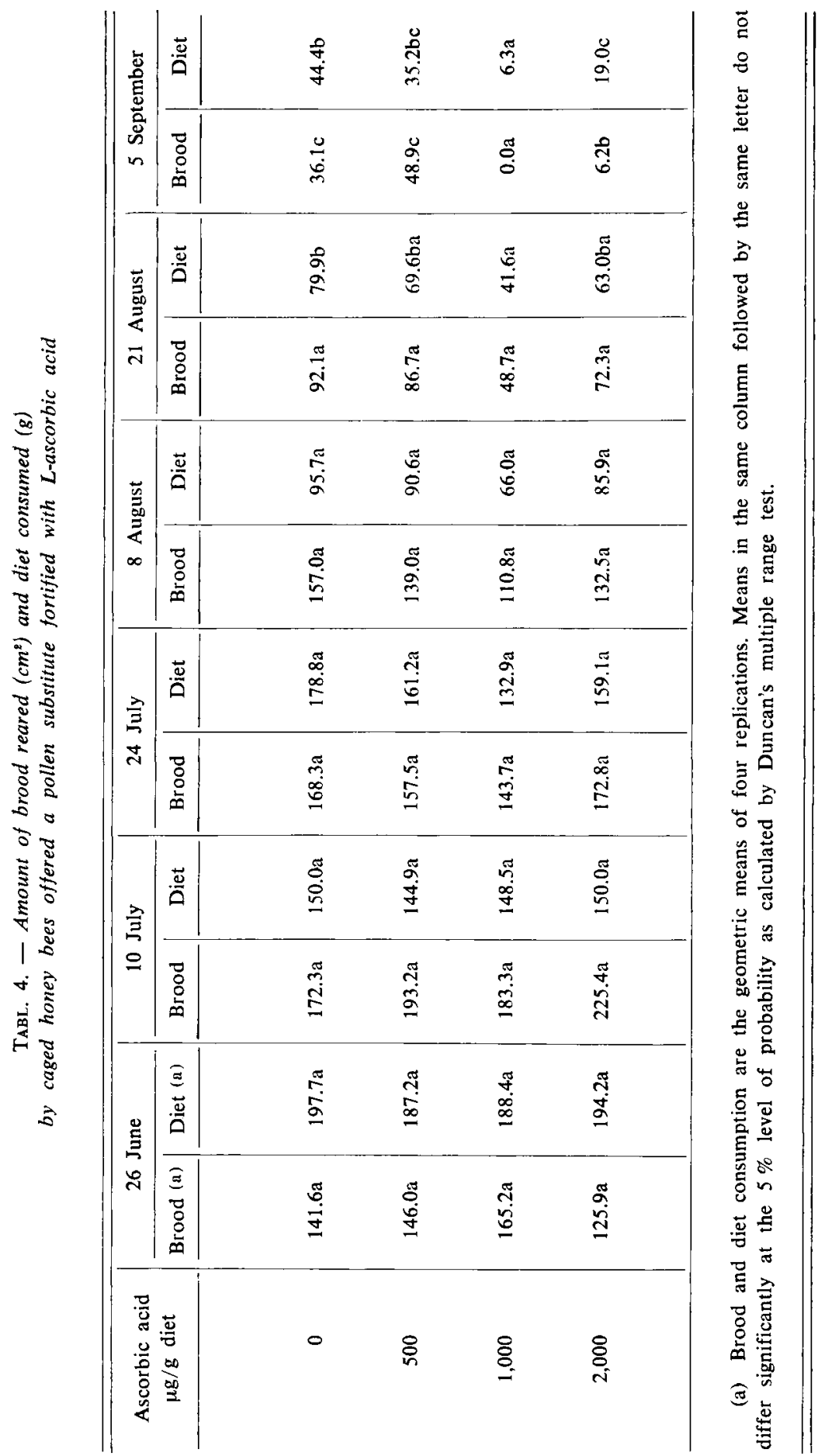




\section{Caged bees}

The amount of diet consumed and number of pupac reared by caged bees is shown in table 4 . The levels of vitamin $\mathrm{C}$ incorporated in the diet in this study were identical to the levels in the 1983 study (HERBERT et al., 1985) except in the present study a pollen substitute was utilized instead of a synthetic diet. The pollen substitute was analyzed and found to be free of vitamin C. During 10 weeks of the study there was no difference in the amount of brood reared by bees offered the various treatments. During the 12 th week, differences in brood rearing were evident but at that time the colonies were less populous than earlier in the study. Overall, significantly more brood was reared by bees fed either the diet supplemented with $500 \mu \mathrm{g} / \mathrm{g}$ ascorbic acid or the vitamin C-free control, followed in decreasing order by bees fed $2000, \mathrm{tg}$ and $1000 \mathrm{fg}$. The analysis of variance indicated a significant difference between dates and diet $\times$ date interaction when brood rearing was the dependent variable. Brood rearing by date showed that most brood was reared on 10 July and the least on 5 Sept.

TABL. 5. - Total vitamin $C$ ( $\mu g$ dehydroascorbic acid and L-ascorbic acid)

in prepupae reared by adult bees offered a pollen substitute fortified with L-ascorbic acid

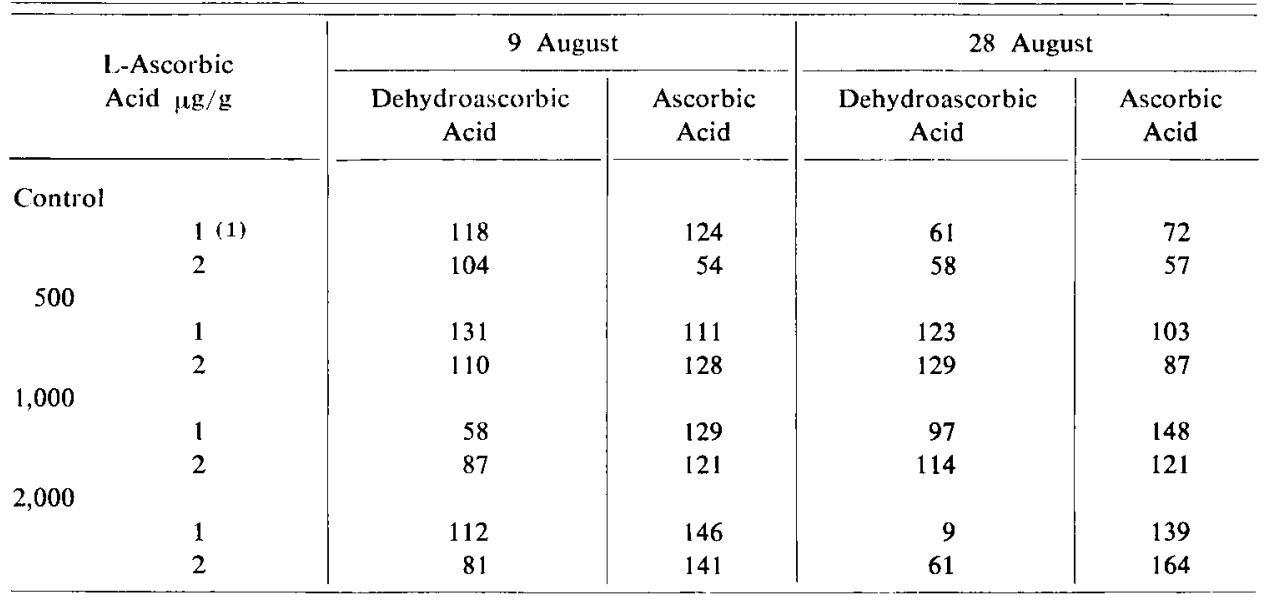

(1) Two nuclei of bees were offered each diet. A total of $1 \mathrm{~g}$ of prepupae were collected for each vitamin $\mathrm{C}$ determination.

The levels of vitamin C ( $\mathrm{kg} / \mathrm{g}$ body mass) in prepupae reared by bees offered each diet regime are shown in table 5 . The vitamin $\mathrm{C}$ was widely distributed in prepupal tissue but within a range of 115 (control \#2 on 28 Aug.) and $258 \mathrm{lg} / \mathrm{g}$ (2000 $\mathrm{\mu g} / \mathrm{g} \# 2$ on 9 Aug.). The levels of vitamin $\mathrm{C}$ in the body tissue were considerably smaller than the levels of L-ascorbic acid incorporated in the diet (500- $2000 \mathrm{fg})$ which may indicate that bees retain little of this vitamin in 
their body mass. Honey bees are apparently able to synthesize vitamin $\mathrm{C}$ using simple precursors since bees fed the vitamin $\mathrm{C}$ free control had equivalent levels of ascorbic acid to those fed the enriched diets.

\section{DISCUSSION}

The pollen traps were effective for small samples of pollen since $1 \mathrm{~g}$ was adequate for vitamin $\mathrm{C}$ determinations with the exception of the Aug 20 collections. Since the vitamin $\mathrm{C}$ determinations were performed the same day, the trapping period was restricted to a $3 \mathrm{hr}$ period between $1000-1300 \mathrm{hr}$. This period was adequate for early spring collections but in mid-summer (July-Aug.) and late summer (Sept.) much of the pollen seemed to be collected later in the day. According to Stewart and Shimanuki (1970), at least one-third of all entering pollen loads were collected in their traps. However, we noticed if the traps were on the colonies longer than $3 \mathrm{hr}$ the nurse bees began to remove small amounts of pollen from the collection tray. The nurse bees became proficient at removing pollen from the trays especially during periods of pollen dearth (Sept.) so at that time we had to modify the traps to include a protective screen to cover the collected pollen.

The vitamin $\mathrm{C}$ levels in fresh bee collected pollen were greatest in pollen samples collected on 4 May and smallest on 6 Aug. These levels agree with the results of an earlier study by HERBERT et al. (1985) on the levels of vitamin C in pollen collected in 1983 in the Beltsville area. The pollen families with the greatest amounts of vitamin $\mathrm{C}$ collected in May were Rosaceae, Luguminosea, and Cruciferae.

Although there were no site differences in the amount of pollen collected by bees over all dates, in several instances, however, individual colonies varied greatly in the amount of pollen they collected. For example, one colony at the APRY site collected $5.2 \mathrm{~g}$ of pollen on 6 Aug. (3 $444 \mathrm{~cm}^{2}$ brood at the time) while the second colony at the same location containing approximately the same amount of brood $\left(3199 \mathrm{~cm}^{2}\right)$ collected $51.8 \mathrm{~g}$ of pollen.

In a previous study (HERBERT et al., 1985) where bees were fed a synthetic diet instead of a pollen substitute all the vitamin $\mathrm{C}$ in the body tissue was in the form of $\mathrm{L}$-ascorbic acid. In the present study the vitamin $\mathrm{C}$ was present as both L-ascorbic acid and dehydroascorbic acid. The prepupae reared by bees fed the pollen substitute were heavier than bees reared on a synthetic diet, which may be an indication of better acceptance of the pollen substitue rather than the result of nutritional deficiencies in the synthetic diet.

In summary, pollen proved to be a good but variable source of vitamin $\mathrm{C}$ depending on the date of collection and floral source. There was, however, no 
relationship between the vitamin $\mathrm{C}$ level in the pollen collected and the rate of brood rearing by free flying honey bees. Although fresh pollen possesses high levels of vitamin $\mathrm{C}$, little is retained in the body tissue of prepupae and bees apparently are able to produce this vitamin since prepupae reared by bees fed a vitamin $\mathrm{C}$-free pollen substitute contained levels similar to the levels in prepupae reared on vitamin $\mathrm{C}$ supplemented diets.

Received for publication in May 1985.

Accepted for publication in July 1985.

\title{
RÉSUMÉ
}

\author{
ACTION DES TENEURS EN VITAMINES C DES REGIMES ALIMENTAIRES \\ SUR LE TAUX DE PRODUCTION DE COUVAIN DE COLONIES D'ABEILlES \\ (APIS MELLIFICA L.) EN PLEIN AIR ET EN CAGE
}

Deux fois par semaine, entre $10 \mathrm{~h}$ et $13 \mathrm{~h}$, de mai à septembre, on a placé des trappes à pollen à l'entrée des colonies situées en plein air, pesé le pollen et déterminé les teneurs en vitamine $C$ (acides déshydroascorbique et L-ascorbique). Dans chacune de ces colonies on a mesuré deux fois par semaine, le lendemain du jour où le pollen avait été prélevé, la surface de couvain à l'aide d'une grille de $6,45 \mathrm{~cm}^{2}$ de maille. L'analyse de la vitamine $\mathrm{C}$ a été réalisée en chromatographie liquide à haute pression. La durée totale de l'analyse, y compris l'extraction, a avoisiné $40 \mathrm{~min}$.

Le pollen s'est révélé être une source de vitamine $C$ riche mais variable selon la date de récolte et l'origine florale. En général la vitamine $\mathrm{C}$ est présente sous forme d'acide ascorbique, avec peu d'acide deshydroascorbique. Les teneurs en vitamine $\mathrm{C}$ ont été maximales dans les échantillons de pollen récoltés le 4 mai et minimales dans ceux récoltés le 6 août. Les familles botaniques ayant les plus fortes teneurs en vitamine $\mathrm{C}$ dans leur pollen sont, en mai, les Rosacées, les Légumineuses et les Crucifères. Il n'y a, néanmoins, aucune relation entre la teneur en vitamine $\mathrm{C}$ dans le pollen récolté et le taux d'élevage du couvain. Il y a des différences hautement significatives dans les teneurs en vitamine $\mathrm{C}$ du pollen selon la date de récolte.

Quatre groupes d'abeilles encagées ont reçu un régime à base de succédané de pollen renforcé en acide L-ascorbique à raison de $0,500,1000$ et $2000 \mu \mathrm{g} / \mathrm{g}$ de nourriture respectivement. On a mesuré leur consommation alimentaire et l'élevage du couvain. Les abeilles recevant le régime supplémenté avec $500 \mu / \mathrm{g}$ et les témoins ont élevé significativement plus de couvain que celles qui avaient reçu les régimes contenant 1000 ou $2000 \mu \mathrm{g}$ d'acide L-ascorbique/g. Au cours de l'étude, on a prélevé des échantillons de prénymphes dans les 4 groupes d'abeilles et déterminé la teneur totale en vitamine $\mathbf{C}$ (acide $\mathrm{L}$-ascorbique et déshydrascorbique). La vitamine $\mathrm{C}$ est largement présente dans le tissu des prénymphes, dans une fourchette de $11-258 \mu \mathrm{g} / \mathrm{g}$ de tissu corporel.

Pour la première fois cette étude prouve que les abeilles ou leurs symbiontes microbiens sont capables de produire cette vitamine, puisque des prénymphes de colonies recevant un régime sans vitamine $\mathrm{C}$ ont des teneurs en acide ascorbique équivalentes à celles des prénymphes recevant un régime supplémenté.

\section{ZUSAMMENFASSUNG}

\section{EFFEKT DES DIATTETISCHEN VITAMIN C GEHALTS AUF DIE BRUTAUFZUCHT BEI FREIFLIEGENDEN UND GEKÄFIGTEN VÖLKERN DER HONIGBIENE}

Der Effekt des diätetischen Vitamin C Gehalts auf die Brutaufzucht wurde sowohl bei freifliegenden als auch bei gekäfigten Bienenvölkern untersucht. Dazu wurden den freifliegenden 
Völkern von Mai bis September 1984 in zweiwöchentlichem Abstand (zwischen $10.00 \mathrm{~h}$ und $13.00 \mathrm{~h})$ Pollenfallen am Flugloch angebracht und das Gewicht des Pollens und sein Vitamin C Gehalt (L-Ascorbinsäure und Dehydroascorbinsäure) bestimmt. Der Brutumfang wurde ebenfalls zweiwöchentlich (am Tag nach der Pollensammlung) mit Hilfe eines Drahtgitters, das in Teilstïcke von $6,45 \mathrm{~cm}^{2}$ eingeteilt war, bestimmt. Die Vitamin C-Analyse erfolgte durch Hochdruck-Flüssigchromatographie. Die Analyse brauchte einschließlich der Extraktion ca. 40 min.

Pollen erwies sich als eine reiche aber variable Vitamin C-Quelle, abhängig vom Zeitpunkt der Sammlung und den Trachtquellen. Im allgemeinen lag das Vitamin $\mathrm{C}$ in Form von Ascorbinsäure vor und nur sehr wenig Dehydroascorbinsäure. Der Vitamin C-Gehalt war am größten in der Stichprobe vom 4. Mai und am geringsten in der vom 6. August. Die Pollenfamilien mit dem größten Vitamin C-Gehalt, die im Mai gesammelt wurden, waren Rosaceen, Leguminosen und Cruziferen. Es gab jedoch keinen Zusammenhang zwischen Vitamin C-Gehalt des gesammelten Pollens und der Brutaufzuchtrate. Es gab hoch signifikante Unterschiede im Vitamin C-Gehalt des Pollen in Abhängigkeit vom Datum der Sammlung.

Die gekäfigten Bienen wurden mit einem Pollenersatzmittel gefüttert, das mit $0,500,1000$ oder $2000 \mu \mathrm{g}$ L-Ascorbinsäure/g angereichert war, und ihr Verbrauch sowie die Brutaufzuchtrate gemessen. Von den Bienen, denen 0 oder $500 \mu \mathrm{g} / \mathrm{g}$ gefüttert wurde, wurde signifikant mehr Brut aufgezogen als von denen mit 1000 oder $2000 \mu \mathrm{g} / \mathrm{g}$ L-Ascorbinsäure. Während des Versuchs wurden auch Proben von Präpuppen aus den Völkern mit den verschiedenen Diäten entnommen und deren Vitamin C (L-Ascorbinsäure und Dehydroascorbinsäure) Gehalt bestimmt. Das Vitamin $\mathbf{C}$ ist im Gewebe der Präpuppen weit verbreitet jedoch mit einer Streuung von 115-258 $\mu \mathrm{g} / \mathrm{g}$ Körpergewebe. Diese Untersuchung zeigte zum ersten Mal, daß die Bienen oder ihre mikrobiellen Symbionten in der Lage sind, dieses Vitamin zu produzieren, da Präpuppen von Völkern, denen Diäten ohne Vitamin C verfüttert wurden, den gleichen Gehalt an Arcorbinsäure aufwiesen wie solche, die mit angereichertem Futter versorgt wurden.

\section{LITERATURE CITED}

Anderson L.M., Dietz A., 1976. - Pyridoxine requirement of the honey bee (Apis mellifera) for brood rearing. Apidologie, 7, 67-84.

BaCK E., 1956. - Influence of the vitamins in pollen on the longevity of honey bees, the development of their pharyngeal glands and their ability to rear brood. Insectes Sociaux, 3, 285-292.

Hagedorn H.H., Burger M., 1968. - Effect of the age of pollen used in pollen supplements on their nutritive value for the honeybee. II. Effect of vitamin content of pollens. J. Apic. Res., 7, 97-101.

HAYDAK M.H., Dietz A., 1965. - Influence of the diet on the development and brood rearing of honeybees. Proc. Int. Beekeeping Congr., Bucharest, 20, 158-162.

Haydak M.H., DieTz A., 1972. - Cholesterol, pantothenic acid, pyridoxine, and thiamine requirements of honeybees for brood rearing. J. Apic. Res., 11, 105-109.

Herbert E.W. Jr., Shimanukr H., 1981. - Cholesterol and salt requirements for brood rearing by honey bees fed a pollen substitute. Am. Bee J., 121 (8), 572-574.

Herbert E.W. Jr., Vanderslice J.T., Higgs D.J., 1985. - Vitamin C enhancement of brood rearing by caged honey bees fed a chemically defined diet. Arch. Insect Biochem. and Physiol., 2, 29-37.

SERIAN-BACK E., 1961. - Vitamine - wichtige Faktoren in der Bienenernährung. Z. Bienenforsch., 5, 234-237.

Stewart J.D., Shimanuki H., 1970. - Rapid-sample pollen trap for honey bees. J. Econ. Entomol., 64, 1350.

VANDERSLiCe J.T., Higgs D.J., 1984. - HPLC analysis with fluorometric detection of vitamin C in food samples. J. Chromatogr., 22, 485-489.

Vivino A.E., Palmer L.S., 1944. - The chemical composition and nutritional value of pollens collected by bees. Arch. Biochem., 4, 129-136. 